\title{
Exceptional Durability of Solid Oxide Cells
}

\section{Ebbesen, Sune; Mogensen, Mogens Bjerg}

\section{Published in:}

Electrochemical and Solid-State Letters

Link to article, DOI:

10.1149/1.3455882

Publication date:

2010

\section{Document Version}

Publisher's PDF, also known as Version of record

Link back to DTU Orbit

Citation (APA):

Ebbesen, S., \& Mogensen, M. B. (2010). Exceptional Durability of Solid Oxide Cells. Electrochemical and SolidState Letters, 13(9), B106-B108. https://doi.org/10.1149/1.3455882

\section{General rights}

Copyright and moral rights for the publications made accessible in the public portal are retained by the authors and/or other copyright owners and it is a condition of accessing publications that users recognise and abide by the legal requirements associated with these rights.

- Users may download and print one copy of any publication from the public portal for the purpose of private study or research.

- You may not further distribute the material or use it for any profit-making activity or commercial gain

- You may freely distribute the URL identifying the publication in the public portal

If you believe that this document breaches copyright please contact us providing details, and we will remove access to the work immediately and investigate your claim 


\title{
Exceptional Durability of Solid Oxide Cells
}

\author{
Sune Dalgaard Ebbesen ${ }^{\mathrm{Z}}$ and Mogens Mogensen*
}

Fuel Cells and Solid State Chemistry Division, Ris $\phi$ National Laboratory for Sustainable Energy,

The Technical University of Denmark, 4000 Roskilde, Denmark

Extensive efforts to resolve the degradation normally associated with solid oxide electrolysis cells (SOECs) have been conducted during the past decade. To date, the degradation is assumed to be caused by adsorption of impurities in the cathode, although no firm evidence for this degradation mechanism has been presented. In this article, we demonstrate that the rapid degradation of these SOECs is indeed caused by impurities, and that operation without degradation is possible when removing these impurities from the inlet gases. Cleaning the inlet gases may be a solution for operating SOECs without long-term degradation. (C) 2010 The Electrochemical Society. [DOI: 10.1149/1.3455882] All rights reserved.

Manuscript submitted May 12, 2010; revised manuscript received May 25, 2010. Published June 22, 2010.

Production of synthetic hydrocarbon fuels from renewable energy is a solution to reduce oil consumption and carbon dioxide emissions without the need for modifications of existing infrastructure, e.g., in the production of methane (synthetic natural gas) or petrol/diesel, the infrastructure already exists in many countries. The raw material for synthetic hydrocarbon fuels is synthesis gas $\left(\mathrm{H}_{2}\right.$ $+\mathrm{CO}$ ), which is traditionally produced via coal gasification or steam reforming of natural gas. Both processes consume fossil fuels and emit greenhouse gases. Coelectrolysis of $\mathrm{H}_{2} \mathrm{O}$ and $\mathrm{CO}_{2}\left(\mathrm{H}_{2} \mathrm{O}\right.$ $+\mathrm{CO}_{2} \rightarrow \mathrm{H}_{2}$ cathode $+\mathrm{CO}_{\text {cathode }}+\mathrm{O}_{2}$ anode $)$ using renewable energy sources may be an alternative route for producing synthesis gas without consumption of fossil fuels and without emitting greenhouse gases. $\mathrm{CO}_{2}$ captured from air and/or recycling or reusing of $\mathrm{CO}_{2}$ from energy systems combined with coelectrolysis of $\mathrm{H}_{2} \mathrm{O}$ and $\mathrm{CO}_{2}$ seems to be an attractive method to provide $\mathrm{CO}_{2}$ neutral synthetic hydrocarbon fuels.

Solid oxide electrolysis cells (SOECs) have the potential for cost-competitive production of hydrogen ${ }^{1-4}$ and carbon monoxide, ${ }^{1}$ providing lifetimes of the SOECs exceeding 5-10 years. ${ }^{1,4}$ However, the state-of-the-art cells, which possess the necessary high performance, degrade rapidly during electrolysis operation. ${ }^{5-13}$ This degradation prohibits the realization of cheap production of hydrogen and carbon monoxide via high temperature electrolysis. The degradation occurs mainly at the Ni/yttria-stabilized zirconia (YSZ) cathode and is most likely due to the adsorption of impurities, ${ }^{5-7,9,13}$ which tend to migrate to the grain boundaries. Thereby, the active triple phase boundary (TPB) gets blocked, which mainly leads to an increase in the polarization resistance. The poisoning effect of impurities in the gas stream by deposition/chemisorption at or in the vicinity of the active TPB in solid oxide fuel cells is a well-known problem. ${ }^{14-20} \mathrm{~A}$ worldwide research effort has been undertaken to develop solid oxide cells (SOCs) and systems with a higher tolerance toward specific impurities. ${ }^{17-20}$ Within the past decade, the degradation of SOECs due to impurities has become increasingly recognized, ${ }^{5-7,9,13}$ although no firm evidence for this degradation mechanism has yet been presented.

In this article, we demonstrate for the first time that the rapid degradation of these SOECs is indeed caused by impurities and that operation without degradation is possible if these impurities were removed from the inlet gases. Cleaning the inlet gases may be a solution for operating these Ni/YSZ-based SOECs without longterm degradation, which allows for cost-competitive production of hydrogen and synthesis gas as well as for the production of synthetic hydrocarbon fuels from renewable energy sources.

\section{Experimental}

Standard planar Ni/YSZ-supported SOCs of $5 \times 5 \mathrm{~cm}$ with an active electrode area of $4 \times 4 \mathrm{~cm}$ produced at Ris $\emptyset$ National Labo-

\footnotetext{
* Electrochemical Society Active Member.

${ }^{\mathrm{z}}$ E-mail: SUEB@risoe.dtu.dk
}

ratory for Sustainable Energy, The Technical University of Denmark were used for all experiments. To investigate the effect of the impurities in the applied gases, the initial performance and electrolysis durability were examined with the gases applied as received $\left(\mathrm{CO}_{2}\right.$ : industrial grade, $\mathrm{CO}_{2} \geq 99.7 \%$, Air Liquide; $\mathrm{CO}$ : grade N-20, CO $\geq 99.0 \%$, Air Liquide) and by cleaning the inlet gases to the $\mathrm{Ni} /$ YSZ electrode. The method for cleaning the inlet gases to both $\mathrm{Ni} / \mathrm{YSZ}$ and lanthanum strontium manganite (LSM)/YSZ is presently subject to a pending patent application ${ }^{21}$ and will be described in a later publication. Because this study was carried out in dry $\mathrm{CO}_{2} / \mathrm{CO}$, the setup-related degradation that had been observed for steam electrolysis in SOECs ${ }^{5}$ can be excluded because the setuprelated impurities were only affected due to the increased impurity mobility caused when introducing steam.

By comparing the observed degradation for the two experiments, the influence of the impurities in the inlet gases becomes evident. The experiment applying the gases as received was previously described in detail elsewhere. ${ }^{7}$ In the previous study, sulfur was detected in the inlet gases, and it was concluded that the degradation was caused by the adsorption of a minute concentration $(\sim 6$ to $\mathrm{ppb})$ of, among others, sulfur impurities at the Ni/YSZ electrode. ${ }^{7}$ Because the degradation of the SOC operated as electrolysis cells was a consequence of impurities adsorbing in the Ni/YSZ electrode, only the inlet gases to the Ni/YSZ electrode were cleaned.

\section{Results and Discussion}

After testing the initial performance of the cell, durability in the electrolysis mode was examined at $850^{\circ} \mathrm{C}$ with $70 \% \mathrm{CO}_{2}-30 \% \mathrm{CO}$ supplied to the $\mathrm{Ni} / \mathrm{YSZ}$ electrode and a current density of $-0.25 \mathrm{~A} / \mathrm{cm}^{2}$. The evolution of the cell voltage with time for the test is shown in Fig. 1. When applying the gases as received, the cell voltage increased drastically during electrolysis operation (Fig. 1). The rate of cell voltage degradation was $0.352 \mathrm{mV} / \mathrm{h}$ during the first $500 \mathrm{~h}$ of operation. This increase in cell voltage corresponds to an increase in the area specific cell resistance (ASR) from 0.37 to $1.07 \Omega \mathrm{cm}^{2}$, which is an increase of $375 \% / 1000 \mathrm{~h}$ of operation. Such high degradation is unacceptable for the long-term operation of these cells. After operation for around $500 \mathrm{~h}$, the cell voltage leveled off and reached a plateau with a limited degradation rate of $0.048 \mathrm{mV} / \mathrm{h}$ only. This increase in cell voltage corresponds to an increase in ASR of $0.04 \Omega \mathrm{cm}^{2}$ or $20 \% / 1000 \mathrm{~h}$ of operation. Although lower than the initial degradation, such degradation is still unacceptable for the long-term operation of these cells.

The durability during electrolysis when applying cleaned inlet gases was examined at identical electrolysis conditions, as the test showed above (Fig. 1). The evolution of cell voltage with time for the test when applying cleaned gases is also shown in Fig. 1. From the cell voltage measured during $\mathrm{CO}_{2}$ electrolysis with cleaned inlet gases to the $\mathrm{Ni} / \mathrm{YSZ}$ electrode, no degradation was observed. The cell voltage during the $600 \mathrm{~h}$ of $\mathrm{CO}_{2}$ electrolysis was $980 \mathrm{mV}$ (Fig. 1). This cell voltage corresponds to an ASR of $0.26 \Omega \mathrm{cm}^{2}$.

A long-term degradation for the SOECs during electrolysis was observed by the course of the cell voltage (Fig. 1) when applying the 


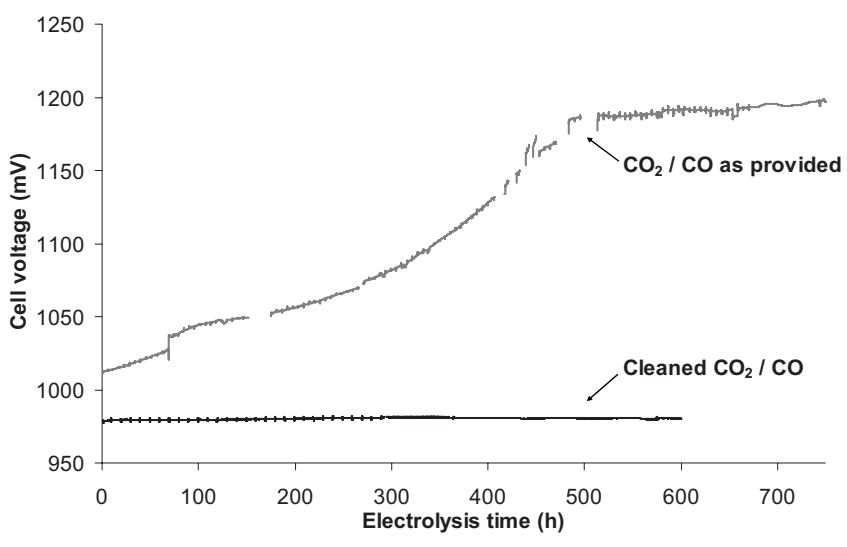

Figure 1. Cell voltage measured during $\mathrm{CO}_{2}$ electrolysis $\left(850^{\circ} \mathrm{C}\right.$, $-0.25 \mathrm{~A} / \mathrm{cm}^{2}, 70 \% \mathrm{CO}_{2}-30 \% \mathrm{CO}$ ) in the Ni/YSZ-based SOC when applying the inlet gases to the Ni/YSZ electrode as received and when applying cleaned gases.

gases as received. However, this study clearly shows that no degradation occurs when applying cleaned inlet gases as long as the cells are operated at mild conditions. Consequently, the durability of these SOCs is heavily influenced by minute concentrations $(\sim 6$ to 7 ppb) ${ }^{7}$ of impurities in the inlet gases. The ASR of $0.26 \Omega \mathrm{cm}^{2}$ when applying cleaned gases is well below the initial ASR when applying the gases as received, which indicates that these cells may be heavily degraded even during the initial start-up and characterization. ${ }^{\top}$ Figure 2 shows the initial polarization characterization (performance) of these Ni/YSZ-based SOCs when cleaning the inlet gases to the Ni/YSZ electrode. When applying cleaned gases, the ASR at $850^{\circ} \mathrm{C}$ was $0.19 \Omega \mathrm{cm}^{2}$ for the reduction of steam (electrolysis mode) and $0.18 \Omega \mathrm{cm}^{2}$ for the oxidation of hydrogen (fuel cell mode) in $50 \% \mathrm{H}_{2} \mathrm{O}-50 \% \mathrm{H}_{2}$. In $50 \% \mathrm{CO}_{2}-50 \%$ $\mathrm{CO}$, the ASR at $850^{\circ} \mathrm{C}$ was $0.24 \Omega \mathrm{cm}^{2}$ for the reduction of carbon dioxide and $0.23 \Omega \mathrm{cm}^{2}$ for the oxidation of carbon monoxide. Increasing the carbon dioxide concentration to $70 \% \mathrm{CO}_{2}(70 \%$ $\mathrm{CO}_{2}-30 \% \mathrm{CO}$ ) showed higher ASR values of $0.27 \Omega \mathrm{cm}^{2}$ for the reduction of carbon dioxide and $0.26 \Omega \mathrm{cm}^{2}$ for the oxidation of carbon monoxide. For coelectrolysis mixtures of $45 \% \mathrm{H}_{2} \mathrm{O}-45 \%$ $\mathrm{CO}_{2}-10 \% \mathrm{H}_{2}$, the ASR was $0.28 \Omega \mathrm{cm}^{2}$ during reduction and $0.30 \Omega \mathrm{cm}^{2}$ during oxidation.

Similar exceptional effect (operation without degradation) of cleaning the inlet gases to the Ni/YSZ electrode has also been observed for steam electrolysis and coelectrolysis of steam and carbon

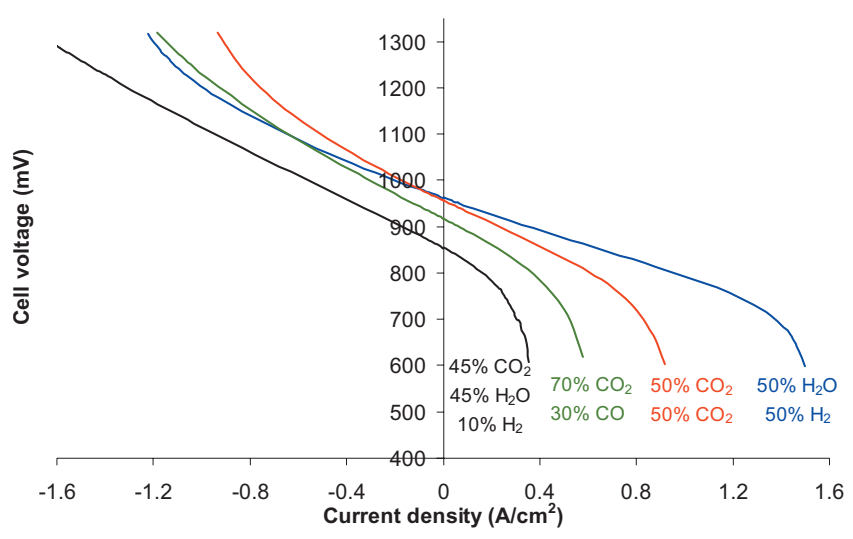

Figure 2. Performance of the Ni/YSZ-based SOC during steam or carbon dioxide electrolyses and during coelectrolysis of steam and carbon dioxide at $850^{\circ} \mathrm{C}\left(50 \% \mathrm{H}_{2} \mathrm{O}-50 \% \mathrm{H}_{2}, 50 \% \mathrm{CO}_{2}-50 \% \mathrm{CO}, 70 \% \mathrm{CO}_{2}-30 \% \mathrm{CO}\right.$, and $45 \% \mathrm{H}_{2} \mathrm{O}-45 \% \mathrm{CO}_{2}-10 \% \mathrm{H}_{2}$ ). dioxide at current densities up to $-0.75 \mathrm{~A} / \mathrm{cm}^{2}$. Integrating electrolysis cells into an intermittent energy cycle involves the operation of the cell as both an electrolysis cell and a fuel cell. When operating the SOC as fuel cells, an extreme effect of cleaning the inlet gases has been observed. In this case, a large improvement of the durability is observed both when cleaning the inlet gases to the $\mathrm{Ni} / \mathrm{YSZ}$ electrode and to the LSM/YSZ electrode.

By evaluating the economic potential for high temperature electrolysis via SOECs, it becomes clear that a cell lifetime of at least 5-10 years is necessary. ${ }^{1,4}$ Based on the results shown in this article, the requirement of a lifetime of at least 10 years seems to be fulfilled, even though this must be demonstrated over a much longer period. The developed gas cleaning process is relatively cheap, and the economic impact on the entire system is only minor. ${ }^{21}$ Nevertheless, including the economic impact for cleaning the inlet gases, a process applying SOECs for the production of hydrogen would thereby be able to produce hydrogen at a price of $\$ 2.5 / \mathrm{kg} \mathrm{H}_{2}$ (20 US $\notin / \mathrm{m}^{3} \mathrm{H}_{2}$ ) (economic assessment as previously performed ${ }^{1}$ ) at an electricity price of $6.3 \mathrm{US} \phi / \mathrm{kWh}^{22}$ (average electricity price for industrial customers in Europe in 2007). This production cost is within the target set up by the U.S. Department of Energy ${ }^{23}$ (target of $\$ 2-3 / \mathrm{kg} \mathrm{H}_{2}$ ). Similarly, a process applying SOECs operating on a mixture of steam and carbon dioxide (collected from the atmosphere ${ }^{24}$ ) would, in combination with the Fischer-Tropsch synthesis, be able to produce synthetic gasoline at a price of $\$ 0.93 / \mathrm{L}$. ${ }^{1,25}$ The production cost of hydrogen and synthetic hydrocarbon fuels via SOECs is a factor of 2 higher than today's hydrogen production price via steam reforming $\left(\$ 1.5-1.9 / \mathrm{kg} \mathrm{H}_{2}{ }^{26}\right)$ or the spot price of gasoline $\left(\sim \$ 0.5 / \mathrm{L}\right.$ gasoline today but $\sim \$ 0.9 / \mathrm{L}$ in $\left.2008{ }^{27}\right)$. The electricity price contributes to a large part of the production cost of both hydrogen and synthesis gas as well as synthetic gasoline. To produce synthetic gasoline at the same cost as today's spot price of gasoline, an electricity price as low as $3.3 \mathrm{US} \phi / \mathrm{kWh}$ is necessary. If a large amount of wind energy will be produced in the future, electricity for such a price will be available for some periods, e.g., during windy nights. In this case, also the hydrogen production via electrolysis in SOECs is competitive with production via steam reforming. However, if a political demand of sequestration of $\mathrm{CO}_{2}$ from fossil fuel will be enforced in the future, the economy of synthetic hydrocarbon fuels based on renewable electricity seems very interesting.

\section{Conclusion}

The durability of the Ni/YSZ-based SOCs as presented here is heavily influenced by impurities in the inlet gases. The application of an inexpensive and very efficient method for cleaning the inlet gases for these SOCs enables operation without degradation at current densities of up to at least $-0.75 \mathrm{~A} / \mathrm{cm}^{2}$. This is a major technological breakthrough. Realizing the long-term operation of these SOECs without degradation may realize the cost-competitive production of hydrogen and synthesis gas as well as the production of synthetic hydrocarbon fuels without the consumption of fossil fuels and emission of greenhouse gases.

\section{Acknowledgment}

This work was financially supported by The Danish National Advanced Technology Foundation's advanced technology platform "Development of 2nd generation bioethanol process and technology," and the Danish Council for Strategic Research, via the Strategic Electrochemistry Research Center.

Ris $\phi$ National Laboratory for Sustainable Energy, The Technical University of Denmark assisted in meeting the publication costs of this article.

\section{References}

1. S. H. Jensen, P. H. Larsen, and M. Mogensen, Int. J. Hydrogen Energy, 32, 3253 (2007).

2. M. A. Liepa and A. Borhan, Int. J. Hydrogen Energy, 11, 435 (1986).

3. M. Ni, M. K. H. Leung, and D. C. Leung, Int. J. Hydrogen Energy, 32, 4648 (2007).

4. J. Sigurvinsson, C. Mansilla, P. Lovera, and F. Werkoff, Int. J. Hydrogen Energy, 
32, 1174 (2007).

5. A. Hauch, S. H. Jensen, J. B. Bilde-Sørensen, and M. Mogensen, J. Electrochem. Soc., 154, A619 (2007)

6. A. Hauch, S. H. Jensen, S. Ramousse, and M. Mogensen, J. Electrochem. Soc., 153, A1741 (2006).

7. S. D. Ebbesen and M. Mogensen, J. Power Sources, 193, 349 (2009).

8. J. E. O'Brien, C. M. Stoots, J. S. Herring, and J. J. Hartvigsen, Nucl. Technol., 158, 118 (2007).

9. A. Hauch, J. R. Bowen, L. T. Kuhn, and M. Mogensen, Electrochem. Solid-State Lett., 11, B38 (2008).

10. G. Schiller, A. Ansar, M. Lang, and O. Patz, J. Appl. Electrochem., 39, 293 (2009).

11. Z. Zhan, W. Kobsiriphat, J. R. Wilson, M. Pillai, I. Kim, and S. A. Barnett, Energy Fuels, 23, 3089 (2009).

12. J. R. Mawdsley, J. D. Carter, A. J. Kropf, B. Yildiz, and V. A. Maroni, Int. J. Hydrogen Energy, 34, 4198 (2009).

13. S. D. Ebbesen, C. Graves, and M. Mogensen, Int. J. Green Energy, 6, 646 (2009).

14. K. V. Hansen, K. Norrman, and M. Mogensen, J. Electrochem. Soc., 151, A1436 (2004).

15. Y. L. Liu, S. Primdahl, and M. Mogensen, Solid State Ionics, 161, 1 (2003).

16. H. Yokokawa, T. Watanabe, A. Ueno, and K. Hoshino, ECS Trans., 7(1) 133 (2007).
17. L. Aguilar, S. Zha, Z. Cheng, J. Winnick, and M. Liu, J. Power Sources, 135, 17 (2004).

18. Y.-H. Huang, R. I. Dass, Z.-L. Xing, and J. B. Goodenough, Science, 312, 254 (2006).

19. L. Yang, S. Wang, K. Blinn, M. Liu, Z. Liu, Z. Cheng, and M. Liu, Science, 326 126 (2009).

20. M. Gong, X. Liu, J. Trembly, and C. Johnson, J. Power Sources, 168, 289 (2007).

21. S. D. Ebbesen and M. Mogensen, Pat. application pending (2010).

22. International Electricity Prices and Fuel Costs, http://www.eia.doe.gov/, last accessed May 10, 2010

23. DOE Announces New Hydrogen Cost Goal, www.eere.energy.gov/ hydrogenandfuelcells/news_cost_goal.html, last accessed May 10, 2010.

24. K. S. Lackner, The Physics Perspective on Energy Supply and Climate Change - A Critical Assessment, Springer-Verlag, Bad Honnef (2009).

25. M. E. Dry, Encyclopedia of Catalysis, John Wiley \& Sons, New York (2003).

26. IEA Energy Technology Essentials, http://www.iea.org/, last accessed May 10, 2010

27. Spot Prices for Crude Oil and Petroleum Products: Energy Information Administration, http://tonto.eia.doe.gov/dnav/pet/PET_PRI_SPT_S1_M.htm, last accessed May 10, 2010. 